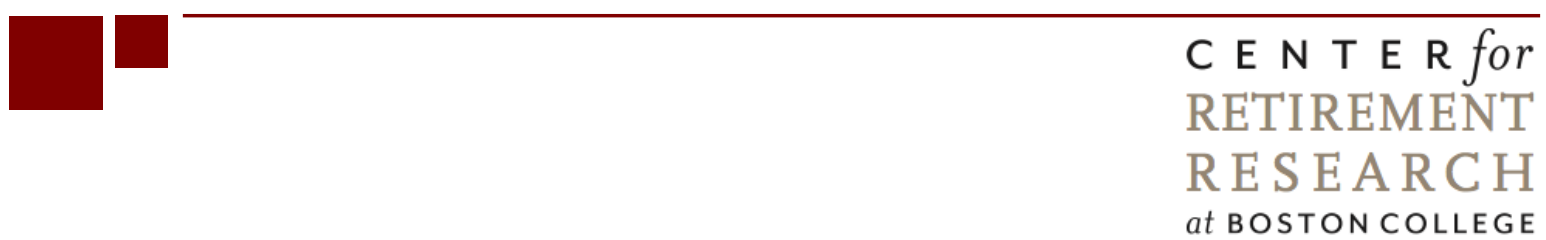

\title{
STICKY AGES: WHY IS AGE 65 STILL A RETIREMENT PEAK?
}

\author{
Norma B. Coe, Mashfiqur R. Khan, and Matthew S. Rutledge \\ CRR WP 2013-2 \\ Submitted: November 2012 \\ Released: January 2013
}
Center for Retirement Research at Boston College
Hovey House
140 Commonwealth Avenue
Chestnut Hill, MA 02467
Tel: 617-552-1762 Fax: 617-552-0191
http://crr.bc.edu

\begin{abstract}
All the authors are with the Center for Retirement Research at Boston College. Norma B. Coe is the associate director of research. Mashfiqur R. Khan is a graduate research assistant. Matthew $\mathrm{S}$. Rutledge is a research economist. The research reported herein was pursuant to a grant from the U.S. Social Security Administration (SSA), funded as part of the Retirement Research Consortium (RRC). The findings and conclusions expressed are solely those of the authors and do not represent the views of SSA, any agency of the federal government, the RRC, or Boston College. All errors are their own.

(c) 2013, Norma B. Coe, Mashfiqur R. Khan, and Matthew S. Rutledge. All rights reserved. Short sections of text, not to exceed two paragraphs, may be quoted without explicit permission provided that full credit, including (C) notice, is given to the source.
\end{abstract}




\section{About the Center for Retirement Research}

The Center for Retirement Research at Boston College, part of a consortium that includes parallel centers at the University of Michigan and the National Bureau of Economic Research, was established in 1998 through a grant from the Social Security Administration. The Center's mission is to produce first-class research and forge a strong link between the academic community and decision-makers in the public and private sectors around an issue of critical importance to the nation's future. To achieve this mission, the Center sponsors a wide variety of research projects, transmits new findings to a broad audience, trains new scholars, and broadens access to valuable data sources.

Center for Retirement Research at Boston College

Hovey House

140 Commonwealth Avenue

Chestnut Hill, MA 02467

phone: 617-552-1762 fax: 617-552-0191

e-mail: crr@bc.edu

crr.bc.edu

Affiliated Institutions:

The Brookings Institution

Massachusetts Institute of Technology

Syracuse University

Urban Institute 


\begin{abstract}
When Social Security’s Full Retirement Age (FRA) increased to age 66 for recent retirees, the peak retirement age increased with it. However, a large share of people continue to claim their Social Security benefits at age 65. This paper explores two potential explanations for the "stickiness" of age 65 as a claiming age: Medicare eligibility and workers' lack of knowledge about their future Social Security benefits. First, we analyze the impact of Medicare eligibility by comparing two groups - one has an FRA of exactly 65; the other, between age 65 and 2 months and age 66. We find that the group with later FRAs who do not have access to retiree health benefits through their employer are more likely to claim Social Security at age 65. We interpret this finding as evidence that Medicare eligibility persuades more people to retire, because they can begin receiving federal health coverage. Individuals without access to retiree health insurance at work are 7.5 percentage points more likely to retire soon after their 65th birthdays and are 5.8 percentage points less likely to delay retirement until the FRA than those with that insurance. This result fits into extensive research showing that access to health insurance is an important component of the retirement decision. On the question of whether misinformation about Social Security benefits may drive individuals to claim at age 65, we find that some individuals are unable to accurately forecast their retirement benefits. However, our analysis suggests that there is no relationship between this confusion and the age 65 peak for claiming Social Security.
\end{abstract}




\section{Introduction}

In order to address an immediate and long-term funding problem, the Social Security Amendments of 1983 gradually increased the Full Retirement Age (FRA), changed the actuarial adjustment for individuals claiming benefits between the early and full retirement ages, and increased the delayed retirement credit. Together, these increase the financial gain to delaying Social Security benefit claims. An extensive literature documents that retirement and claiming decisions are responsive to Social Security incentives (see Krueger and Meyer (2002) for a review), and recent work has shown that individuals are responding to the incentives laid out in the 1983 Amendments. Kopczuk and Song (2008) and Song and Manchester (2007) use administrative data and find that a new peak in claiming ages has appeared at the higher FRA. However, these papers also show that a large age-65 spike remains.

While it is clear that the increases in the FRA are causing changes at the aggregate level, it is not yet known who in particular has altered his or her behavior. Because the increase in the FRA is akin to a benefit cut, traditional economic theory would predict an increase in the retirement age among younger cohorts, but not an increase that is lock-step with the phase-in of the higher FRA. Behaghel and Blau (2011) use individual-level data to try to estimate what characteristics are correlated with delaying claiming until the FRA, and thus estimate, "who is behavioral?” They find that individuals with higher cognitive abilities are most likely to increase their retirement age, and interpret this finding as evidence of reference dependence and loss aversion. However, their focus is purely on who changes their behavior; the focus on this paper is who remains claiming at age-65 even as their FRA changes.

We explore whether two policy-relevant parameters help explain the remaining age-65 spike: understanding of the financial incentives to delay retirement and Medicare eligibility. To understand why age 65 remains "sticky," we estimate hazard models for exiting the labor force, retiring, and claiming Social Security benefits. We then examine whether the accuracy of selfreported Social Security benefit levels are significant determinants of claiming at precisely 65 . Access to health insurance may also play a critical role explaining the age 65 peak. Historically, the Social Security FRA has been 65, the exact same age as the Medicare eligibility age, and thus it has been impossible to determine how much of an effect Medicare eligibility has on retirement behavior. 
This paper continues as follows. Section 2 presents background information. Section 3 presents the model. Section 4 discusses the data. Section 5 presents the results and section 6 concludes that one's ability to predict their Social Security benefits seems, for the most part, unrelated to whether or not they claim benefits, retire, or exit the labor market on the $65^{\text {th }}$ birthday or at their full retirement age. However, we find that individuals without access to retiree health insurance are more likely to retire at age 65, and less likely to postpone retirement until their FRA. We interpret these findings as suggestive evidence of a Medicare-eligibility effect on retirement behavior.

\section{Background}

Historically, the Social Security FRA has been 65, but the 1983 Amendments slowly increased the FRA by birth cohort. Individuals born through 1937 have the FRA of 65, while successive birth years have their FRA increase by 2 months for every year. Individuals born between 1943 and 1954 have a FRA of 66. ${ }^{1}$ Figure 1 illustrates the relationship between claiming age and Social Security benefits by birth cohort. The increase in the FRA reduces the expected present discounted value of Social Security benefits, and if leisure is a normal good, should increase the retirement age. However, the increase in the FRA did not change the slope of the benefit schedule around the FRA, and thus there is no expectation for individuals to increase their retirement age by exactly the 2-months per birth year, as is the FRA increase.

Two other changes in the Social Security program during the period we study may also impact claiming behavior. First, the 1983 reforms increased the delayed retirement credit (DRC) - the increase in benefits one receives if they postpone claiming until after their FRA - as well as increasing the FRA. However, the DRC increases only every other birth-year, and thus does not increase at the same time as the FRA. Second, in 2000, the earnings test was eliminated for individuals working beyond their FRA. This change could increase the claiming hazard right at the FRA since workers would no longer be tempted to delay claiming in order to avoid this tax, but there is no reason to think it would impact the age-65 claiming spike. Fortunately, there is not complete overlap between the cohorts impacted by the earnings test removal and the FRA

\footnotetext{
${ }^{1}$ The FRA again increases by 2 months for each birth year until it reaches 67 for people born in or after 1960, but these birth cohorts have not yet reached FRA and thus are outside of our analysis.
} 
increases, allowing researchers to identify the effects separately (Song and Manchester 2008; Behaghel and Blau 2011).

Much attention has been paid to the effect the increase in the FRA has on retirement timing (Blau and Goodstein 2010, Kopczuck and Song 2008, Pingle 2006, Mastrobuoni 2009, Song and Manchester 2008, Behaghel and Blau 2011). Kopczuk and Song (2008) and Song and Manchester (2008) use aggregate claiming data and find that a new peak in claiming ages has appeared at the higher FRA, but a smaller age-65 claiming spike remains.

Behaghel and Blau (2011) use individual-level data from the Health and Retirement Study (HRS) and the Longitudinal Employer-Household Dynamics (LEHD) to explore how individual characteristics are related to the responsiveness of the retirement decision to the FRA. They find that pension incentives, wealth, and workers with high cognitive skills are more likely to respond to the FRA increase and retire later. However, the focus of their study is to identify who is changing their retirement age, while the emphasis of this study is who is not. This paper sets out to test why the age-65 spike remains, and whether it can be explained by Medicare availability or a lack of knowledge about Social Security program.

This paper fits in two strands of the economic literature surrounding retirement behavior. First, it contributes to the relatively small literature that examines the effect of the FRA increase on retirement. Song and Manchester (2008) and Kopczuk and Song (2008) offer thorough examinations of the effects of the changes in the FRA on claiming decisions, but since they use administrative data they cannot determine why the age-65 spike has survived despite the gradual increase of the FRA.

Secondly, it fits in the rather extensive literature that finds that access to health insurance is an important component of the retirement decision. While the size of the impact is debated, the literature is virtually unanimous that access to health insurance as a retiree increases the probability of retirement (see Monk and Munnell (2009) for a review). The current evidence on the role of Medicare in the retirement decision is derived from simulations based on structural models. Rust and Phelan (1997) conclude that Medicare is important; Blau and Gilleskie (2006, 2008) conclude that it was much less important in the 1990s. Estimates from French and Jones (2011) are in between. However, since the Social Security FRA and Medicare eligibility ages have only recently been decoupled, this paper is the first to estimate the relative importance of Medicare in the claiming decision directly. 


\section{Data}

This paper uses the Health and Retirement Study (HRS) in order to estimate the effect of the changes in the Social Security program on the Social Security benefits claiming age. We linked the HRS to the Social Security Administration (SSA) administrative earnings history data in order to (1) adequately control for lifetime earnings; and (2) correctly calculate the individual's Average Indexed Monthly Earnings (AIME) and financial incentives to retire.

The HRS is a biennial household survey of individuals over the age of 50 and their spouses. The survey began in 1992 with the 1931-1941 birth cohorts, with additional cohorts added over time. This study uses individuals born between 1931 and 1944, all of whom have reached their FRA by 2010. The treatment cohorts are those born 1938-1944, whose FRA is between 65 and 2 months and 66 years, while the control group are those born before 1938, when the FRA is $65^{\text {th }}$ birthdays. For the primary analysis we select individuals with observable labor market status between the ages of 64 and 66. We drop individuals who report receiving Social Security benefits before age 62, as they likely receive disability benefits and thus are automatically rolled into the retirement program at their FRA. The remaining sample consists of 3,717 individuals among whom 1,608 individuals are in the treatment group and 2,109 individuals are in the control group.

We examine three labor force outcomes between the $64^{\text {th }}$ and $66^{\text {th }}$ birthdays: self-reported labor force exit, self-reported retirement, and Social Security claiming age. Using the detailed job history questions, we construct a monthly employment history for each individual. The selfreported age of labor force exit is defined as the month in which the individual first leaves the labor force for at least 3 months, conditional on having been employed in the previous 3 months. The individual reports the year and month he began receiving Social Security retirement benefits (OASI) directly. Finally, self-reported retirement is defined as the first month the individual reports himself to be completely retired, conditional on being in the labor force in the month before his $64^{\text {th }}$ birthday.

Social Security Knowledge: The HRS has very detailed questions about participants’ expected benefits if they claim at their preferred claiming age. ${ }^{2}$ In 2002, they added questions

\footnotetext{
${ }^{2}$ The HRS picks one person within a couple to be the financial respondent. Before 2000, the financial respondent was asked about Social Security benefits for both themselves and their spouse. We assign these expectations to each person in the couple, respectively. After 2000, the financial respondent was only asked about their own Social Security benefit expectations. We assign this one measure to both members of the couple. This attribution suggests
} 
about the benefit they would receive if they claim at age 62 or the FRA as well. We use these questions to assess individuals' knowledge about their own benefits by seeing how their expected benefit aligns with their true benefit calculated from the SSA earnings records. ${ }^{3}$

Health Insurance: In order to measure the importance of Medicare eligibility in the retirement decision, we examine current sources of health insurance coverage. If an individual has employer-sponsored health insurance and no retiree health insurance benefits, we hypothesize he is more likely to retire at age 65 when first Medicare-eligible than individuals who have their health insurance from sources that are not tied to their own employment status. Individuals with retiree health insurance coverage should they retire or health insurance from their spouse's employer should be less responsive to the Medicare eligibility age.

\section{Model}

We compare the claiming behavior of those impacted by the 1983 Amendments who have reached their FRA (born 1938-1944, the treatment group) to those born between 1931 and 1937 with the FRA of 65 (the control group), using a hazard model framework that controls for observable characteristics, such as health and lifetime earnings. Following Behaghel and Blau (2011), we estimate different retirement patterns for the treatment and control groups using difference-in-differences methodology:

$$
P_{i a c}=\alpha F R A_{i a c}+\rho X_{i a c}+\beta_{a}+\gamma_{c}+\varepsilon_{i a c}
$$

where $P_{i a c}$ is one of three outcomes of interest for person $i$ born in cohort $c$ currently at age $a$ : claiming Social Security retirement benefits, exiting the labor force, or reporting that he is retired. ${ }^{4}$ The unit of observation is the person-month between his $64^{\text {th }}$ birthday and either failure (claiming, exiting, or retiring) or censoring (death, survey attrition, or reaching age 66 or calendar year 2010 without failure).

FRA indicates if individual $i$ has reached the full retirement age on or before age $a . \mathrm{X}$ is a set of individual-level controls. We include race, sex, marital status, education, health, health insurance coverage, retiree health insurance coverage, pension coverage, pension type,

that the financial respondent is at least as knowledgeable as the non-financial respondent in terms of Social Security benefits. We test if our results are robust to including only financial respondents in section 5.

${ }^{3}$ See the Appendix for more information on how we calculated the Social Security benefit from the summary earnings records.

${ }^{4}$ The current estimates are from linear probability models, for simplicity. We do not expect these estimates to differ substantially from probit or logit models, as the dependent variable is not close to zero or one in any month. 
household wealth, average hourly earnings, and measures of cognitive capability, planning horizon, and risk aversion. $\beta_{a}$ and $\gamma_{c}$ represent a full set of age (in months) and cohort dummies, respectively. The estimated coefficients on FRA and the age 65 (or 780 months) dummy are the key measures in determining the average responsiveness to the change in financial incentives.

The model also controls for other changes in the Social Security program that may also impact claiming behavior. The 1983 reforms also increased the delayed retirement credit (DRC). However, the DRC increases are cohort-specific, so the effects of this policy change would be absorbed in the birth cohort dummy variables. A second confounding policy change occurred in 2000, when the earnings test was eliminated for individuals working beyond their FRA. This change could increase the claiming hazard right at the FRA since workers would no longer be tempted to delay claiming in order to avoid this tax. Fortunately, there is not complete overlap between the cohorts impacted by the earnings test removal and the FRA increases, so we also include an indicator for individuals in birth cohorts that were not subject to the post-FRA earnings test in some models.

To this main estimating equation, we add interaction terms in order to directly test for different responses to the FRA increase based on access to retiree health insurance. We interact the retiree health insurance indicator with the FRA dummy and each age and birth cohort dummy to allow for the full retirement and claiming patterns to differ by post-retirement health insurance ownership.

We also test whether one's knowledge of Social Security program rules are associated with retirement and claiming patterns. In this set of specifications, we include a categorical variable that summarizes this knowledge at three different ages: 62, FRA, and his expected retirement date. First, for each age, we calculate the difference between the benefit the respondent reports that he expects to receive and the respondent's actual Social Security monthly benefit, as calculated from his earnings. Then, for each of the three ages, we split the sample into five groups: (1) within one standard deviation and positive (slight overestimation, the omitted category from the regression); (2) within one standard deviation and negative (slight underestimation); (3) outside of one standard deviation and positive (large overestimation); (4) outside of one standard deviation and negative (large underestimation); (5) no answer or don't know. We also interact this categorical variable with the FRA dummy and the age and birth cohort dummies. 


\section{Results}

Figures 2-4 illustrate the behavior we find in the HRS: Social Security benefit claiming hazard, exit from employment, and retirement hazards, by birth cohort. Despite the difference in definition of retirement and employment, we find very similar patterns as Behaghel and Blau (2011) by birth cohort. The FRA-claiming spike is the most affected, and moves in lock-step with the increase in the FRA. However, the age-65 spike does not disappear, and remains larger than the age-63 and age-64 spikes.

Table 1 presents the means of the characteristics of our sample, measured as of age 64 . For the most part, there are few demographic differences between our control (1931-1937) and treatment (1938-1942) cohorts. The younger (treatment) cohorts tend to have slightly higher educational attainment, are wealthier, and are less likely to report bad health. They are also less likely to have a defined benefit pension, and more unsure about their pension coverage. About one-half of the sample receives health insurance through their employer, and one-quarter have a spouse that gets health insurance through their employer. Two-thirds to three-quarters of the sample reports no access to retiree health insurance.

Table 2, Panel A presents the estimated impact of the FRA increase on Social Security claiming timing. We present the coefficients on the FRA, the removal of the Social Security Earnings test, age-65 and age-64. Panel B presents these coefficients for the exit from employment. Panel C presents these coefficients for retirement hazard. ${ }^{5}$

Panel A illustrates that our estimated effect of the FRA and the removal of the Social Security test on Social Security claiming behavior are in-line with those reported in Table 1 of Behaghel and Blau (2011). We find a 15 percentage point increase in claiming at the FRA, slightly larger than Behaghel and Blau’s 13-percentage-point estimate, likely due to slight differences in the samples. Our estimate of the effect of the earnings test - those subject to it are 4.7 percentage points less likely to claim - is also about one percentage point larger than Behaghel and Blau's estimate, as well.

In the model presented in Panel B, we find that, compared to individuals retiring at age 64.5 (the omitted age category), exiting the labor market does not follow the FRA increase, but the spike at age 65 remains: individuals in our sample are 1.3 percentage points more likely to exit the labor force during the month they turn 65. Self-reported retirement does follow the FRA

\footnotetext{
${ }^{5}$ The full results of Model 3 are presented in Appendix Table 1.
} 
increase, but again, the hazard at age 65 remains larger than at the FRA. Intuitively it makes sense that self-reported retirement is less responsive to the removal of the earnings test above the FRA than the actual exit from the labor force.

Table 3 presents the summary statistics concerning Social Security expectations. Since the expectations questions are only asked of individuals who have not yet claimed (and some of the questions were added in 2002), our sample size drops when using this metric of Social Security knowledge. One does see a slight increase in the expected age of retirement between the control cohorts and the treatment cohorts. ${ }^{6}$ Expected benefits increase by birth cohort - this could be due to the underlying differences in the cohort characteristics or differences in knowledge about the Social Security program. To determine if it’s a difference in underlying characteristics, we compare it to the calculated Social Security benefits. The mean calculated benefit also increases with birth cohort; but the differences between expected benefits and calculated benefits varies by birth cohort. Interestingly, those born 1938-1942 tend to be the most accurate, on average, despite the complexity of their increasing FRA by 2-months per birth year. Since the expectations of benefits of claiming at 62 and 65 were added in 2002, we do not have these measures for the control cohorts, who were already beyond these ages. For the regressions where we use these measures, we are in essence comparing differences between knowledgeable and unknowledgeable individuals with the same birth cohort.

Since we want a measure of Social Security knowledge, we take the difference between the expected and the calculated benefits for a given claiming age by individual. The distributions of these differences are shown in Figure 5. Panels A, B, and C present claiming at age 62, the FRA, and one's preferred retirement age, respectively. Interestingly, people tend to underestimate their Social Security benefits, since the mean of the distribution is negative in all three cases. As one would expect, individuals are much better at predicting benefits for their preferred retirement age than other ages - the distribution in panel C is much more concentrated and has a larger peak around zero. We then categorize the difference into whether benefits are over- or underestimated, and whether the difference is large or small.

What this paper aims to find is whether there are differential effects of Social Security knowledge or health insurance availability on the likelihood of claiming/exiting the labor

\footnotetext{
${ }^{6}$ It is important to note that these expectations are measured around the age of 64 among those who have not yet claimed Social Security, which is why the mean is relatively high (65-65.6).
} 
force/retiring at age 65. To do so, we modify equation (1) to include information on Social Security knowledge (Table 4) and retiree health insurance access (Table 5), both in levels and interacted with age, FRA, and birth cohort. ${ }^{7}$ Panels A, B, and C are the results from the claiming equation, exit from employment, and retirement hazard, respectively, as in Table 2.

In Table 4, each column presents results from a different equation, with a different interaction term that measures expectations about Social Security benefits at different potential claiming ages. Column 1 measures Social Security knowledge as the difference between one's self-reported benefits if one claimed at 62 and the benefits we calculate from the earnings record for claiming at age 62. Column 2 measures knowledge in the same manner, using benefits that would be claimed at the FRA. Likewise, Column 3 calculates knowledge using the individual's self-reported expected retirement age.

Overall, we find little evidence of a relationship between one's ability to predict their Social Security benefits and the remaining age-65 claiming, retirement, or exiting of the labor force spike. While some of the coefficients are statistically significant - for example, individuals not responding to the question about expected benefits at their self-reported preferred retirement age are less likely to claim at their FRA - they are not consistently significant across models and thus are hard to interpret as robust results.

Table 5 presents the results interacted with whether the individual has no access to retiree health insurance upon retirement, presumably those who would be more sensitive to the Medicare eligibility-age. We find that access to health insurance may help explain the remaining age-65 spike in the retirement hazard, but not in claiming behavior. Individuals without access to retiree health insurance are 7.5 percentage points more likely to report retiring in the month of their $65^{\text {th }}$ birthdays, the Medicare eligibility age, and 5.8 percentage points less likely to delay retirement until the FRA. To further support the idea that this is due to Medicare eligibility, we also report the interaction terms with age 64, which we hypothesize should be insensitive to retiree health insurance since there is not exogenous change in health insurance access at that age. As hypothesized, there is no relationship with claiming right at age 64 and access to retiree health insurance.

The results are largely robust to alternative specifications. One such alternative concerns the role of the financial respondent, the individual who is asked about their expectations for

\footnotetext{
${ }^{7}$ Full results available from the authors upon request.
} 
Social Security benefit amounts for both spouses. It may be the case that the non-financial respondent has different expectations, and we may be incorrectly categorizing the household based on one spouse's ignorance. We limit the estimates to only financial respondents and find the results largely unchanged. ${ }^{8}$

\section{Conclusions}

While we find considerable error in self-reported future Social Security benefit levels, this does not seem to contribute independently to the remaining claiming spike at age 65 . However, we do find that individuals whose health insurance coverage is most tied to their employment - namely people with no retiree health benefits - do seem to contribute to the age65 claiming peak. We interpret this finding as evidence for Medicare-eligibility impacting retirement decisions, something that has not been documented before due to the historical link between the Social Security FRA and the Medicare program.

The results of this paper imply that projections of retirement behavior need to account for the extent to which Medicare eligibility affects retirement and claiming. Currently, the FRA is scheduled to increase to 67, but the Medicare-eligibility age is scheduled to remain at 65 . Numerous policy experts have suggested extending the FRA even further. ${ }^{9}$ The results in this paper suggest that a retirement spike would remain at age 65; indeed, with a larger gap between Medicare eligibility and the FRA, this spike could grow larger relative to the FRA peak, if individuals' health care and health insurance needs supersede the financial incentives to delay retirement.

Other policy experts have expressed interest in increasing the Medicare eligibility age beyond 65 to address budgetary concerns. Such a policy would re-align the health insurance and financial incentives, and could restore the prominent peaks in retirement and claiming at FRA that we observed before 2002. The results of this paper suggest that this policy change would keep older workers in the labor force, and off of Social Security, longer than further FRA extension alone; whether this policy is desirable depends on the relative importance of welfare loss among seniors who would have otherwise retired versus reduced Medicare and Social Security outlays. On the other hand, if health insurance exchanges are implemented as detailed

\footnotetext{
8 Future versions of the paper will also include analysis by gender.

${ }^{9}$ For example, the Bowles-Simpson commission recommends increasing the FRA to 69.
} 
by the Affordable Care Act, concerns about health insurance access need not delay retirement as much as we observe under current conditions. 


\section{References}

Anderson, P.M., Gustman, Alan L., and Thomas L. Steinmeier. 1999. “Trends in Male Labor Force Participation and Retirement: Some Evidence on the Role of Pensions and Social Security in the 1970s and 1980s.” Journal of Labor Economics 17 (4), 757-783.

Behaghel, Luc and David M. Blau. 2011. "Framing Social Security Reform: Behavioral Responses to Changes in the Full Retirement Age.” American Economics Journal: Economic Policy.

Blau, David M. and Donna Gilleskie. 2006. “Health Insurance and Retirement of Married Couples.” Journal of Applied Econometrics 21:935-953.

Blau, David M. and Donna Gilleskie. 2008. "The Role of Retiree Health Insurance in the Employment Behavior of Older Men.” International Economic Review, 49(2): 475-514.

Blau, David M. and Ryan Goodstein. 2010. "Can Social Security Explain Trends in Labor Force Participation of Older Men in the United States?” Journal of Human Resources. 45(2):326-63.

French, Eric and John Bailey Jones. 2011. "The Effects of Health Insurance and Self-Insurance on Retirement Behavior.” Econometrica 79(3): 693-732.

Kapteyn, Arie, Pierre-Carl Michaud, James Smith and Arthur van Soest. 2006. "Effects of Attrition and Non-Response in the Health and Retirement Study.” RAND Corporation, Working Paper WR-407

Kopczuk, Wojciech and Jae Song. 2008. "Stylized Facts and Incentive Effects Related to Claiming of Retirement Benefits Based on Social Security Administration Data.” Working Paper WP2008-200. Ann Arbor, MI: University of Michigan Retirement Research Center.

Krueger, Alan B. and Bruce D. Meyer. 2002. “Labor Supply Effects of Social Insurance.” In Handbook of Public Economics, edited by Alan J. Auerbach and Martin Feldstein, 4: 2327-2392. Amsterdam: North Holland.

Mastrobuoni, Giovanni. 2009. "Labor Supply Effects of the Recent Social Security Benefit Cuts: Empirical Estimates Using Cohort Discontinuities.” Journal of Public Economics 93(1112): 1224-1233.

Monk, Courtney and Alicia H. Munnell. 2009. “The Implications of Declining Retiree Health Insurance.” Working Paper 2009-15. Chestnut Hill, MA: Center for Retirement Research at Boston College.

Pingle, Jonathan F. 2006. "Social Security’s Delayed Retirement Credit and the Labor Supply of Older Men.” Working Paper, Board of Governors of the Federal Reserve System, June. 
Rust, John and Christopher Phelan. 1997. "How Social Security and Medicare Affect Retirement Behavior in a World of Incomplete Markets.” Econometrica 65:781-831.

Song, Jae and Joyce Manchester. 2007. "Have People Delayed Claiming Retirement Benefits? Responses to Changes in Social Security Rules.” Social Security Bulletin 67(2): 1-23.

U.S. Social Security Administration. 2012. "Primary Insurance Amount.” Available at: http://www.socialsecurity.gov/OACT/COLA/piaformula.html. 


\section{Appendix: Social Security Benefit Calculations}

The Social Security benefit calculation is a three step process. First, a worker's previous earnings are restated in terms of today's wages by indexing past earnings to wage growth. Second, earnings for the highest 35 years are then averaged and divided by 12 to calculate Average Indexed Monthly Earnings (AIME). Finally, the Primary Insurance Amount (PIA) is the sum of three separate percentages that are applied to portions of the AIME (SSA 2012). The bend-points are indexed for wage growth, and thus depend on the year in which a person reaches age 62. Specifically, for workers first becoming eligible for benefits in 2013, their PIA is the sum of:

- 90 percent of the worker's first $\$ 791$ of AIME, plus

- 32 percent of AIME between $\$ 791$ and $\$ 4,768$, plus

- 15 percent of any AIME in excess of $\$ 4,768$.

This PIA is continually recalculated as long as the individual remains employed; and is indexed to prices from age 62 . The benefit actually paid depends on when the worker claims. A retiree is entitled to a benefit equal to the PIA at the Full Retirement Age (which was 65 for the first cohort under consideration, 66 for the last cohort). A worker may choose to retire as early as age 62, with reduced benefits. In contrast, if a worker elects to delay receipt of benefits to an age as late as 70 , the eventual benefits are permanently increased for each year of delay.

The administrative data provides Social Security earnings histories back to 1951 for the approximately 70 percent of the sample that has given permission to link. Previous work suggests that giving permission to link is essentially random (Kapteyn et al. 2006). Thus we follow Gustman and Steinmeier (2001) and estimate earnings histories based on survey data on previous jobs and wages, using the estimated returns to tenure from Anderson et al. (1999).

To estimate Social Security benefits in retirement, it is necessary to project earnings beyond the year at which the individual last gave permission to match to the administrative data. Following Gustman and Steinmeier (2001), we make the following 
assumptions about wage growth. For individuals with self-reported earnings in the survey, the assumption is that their real earnings observed in the last reported year persist until their expected retirement date. For those who do not report self-reported earnings, zeros are projected for future years. Future benefits are calculated at three claiming ages to match the expectations questions in the HRS: age 62, the FRA, and the individual's self-reported retirement age. We then put it in current-year dollars to match the year of the expectation questions using the CPI. 
Figure 1. Social Security Retirement Benefits, by Birth Cohort

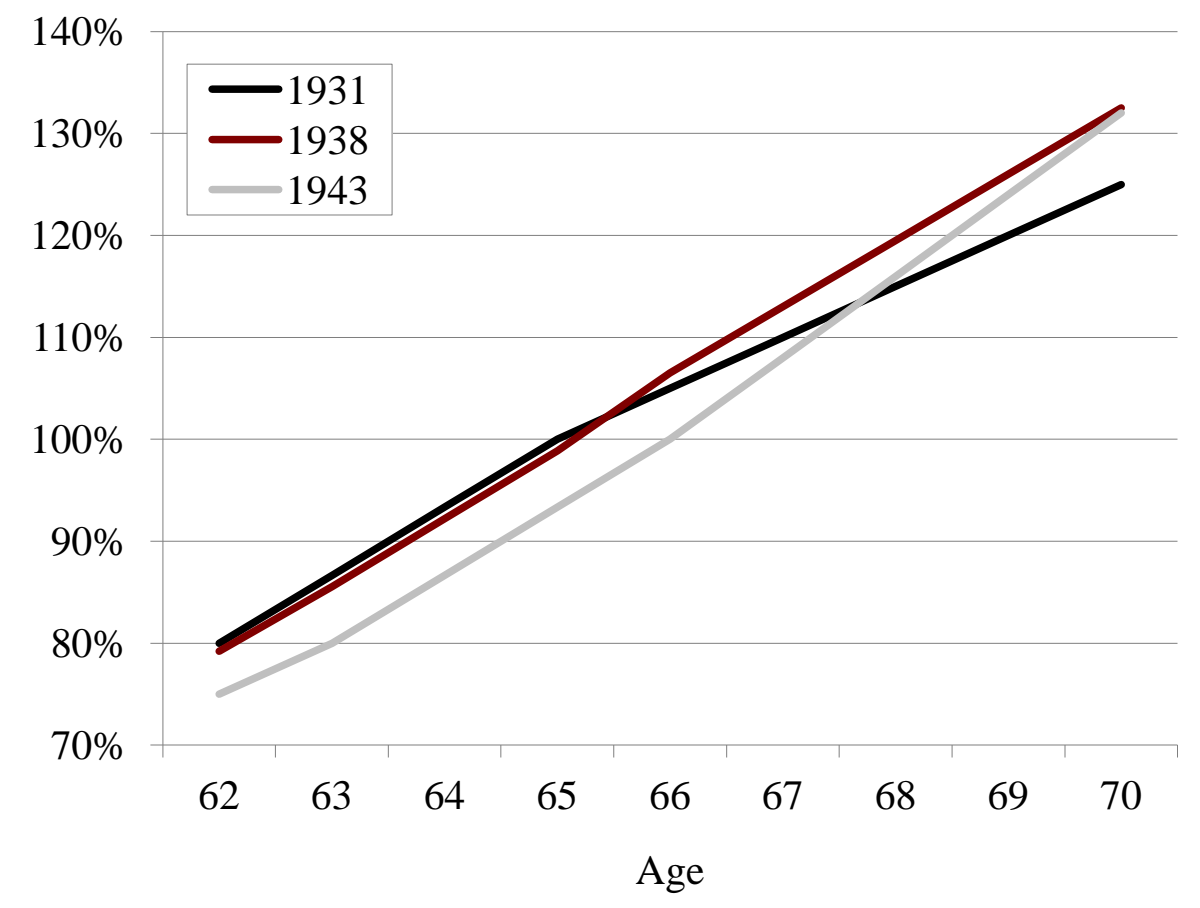




\section{Figure 2: OASI Benefit Claiming Hazard}
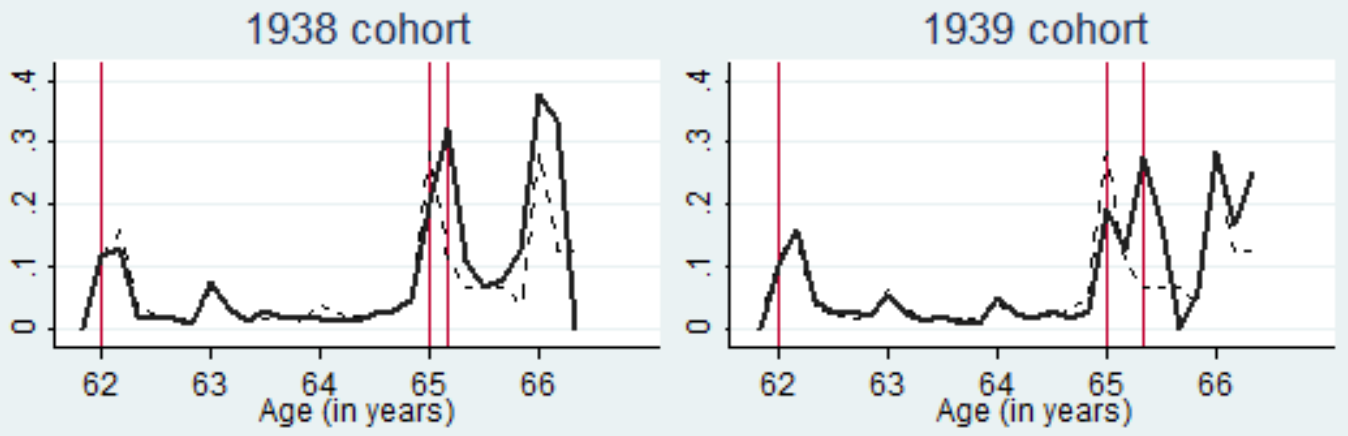

1940 cohort
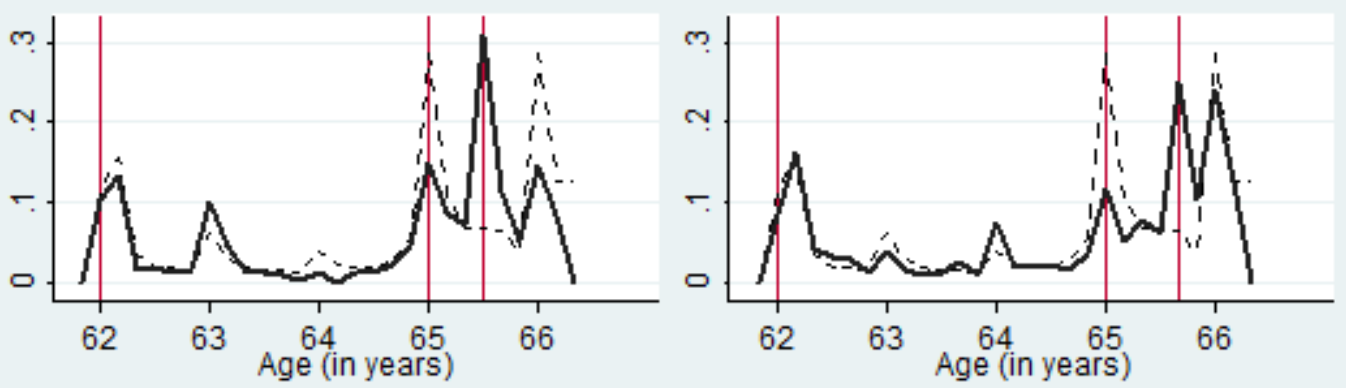

1942 cohort
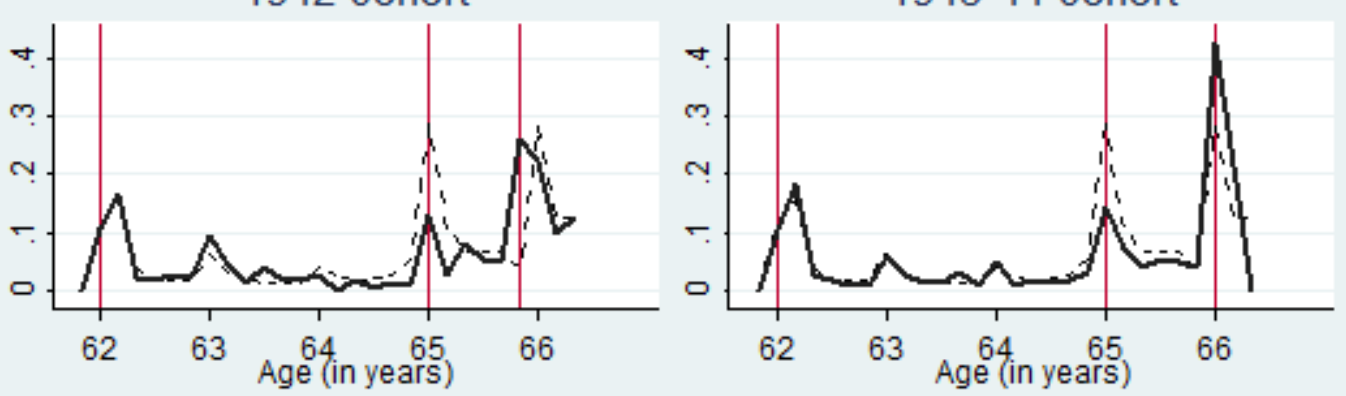

Notes: The graphs show the average monthly claiming hazard rates for cohorts born in between 1931 to 1944. The OASI claiming hazard rate is defined as the probability of claiming at a given age, conditional on not having claimed previously with claiming being an absorbing state. Age is measured at a bimonthly frequency; e.g. age 62 denotes age 744 and 745 in months. In each graph, the dotted line depicts the claiming hazard for workers with Full Retirement Age (FRA) of 65. For each cohort, the vertical lines indicate age 62, age 65, and the FRA. 


\section{Figure 3: Hazard of Exit From Employment}
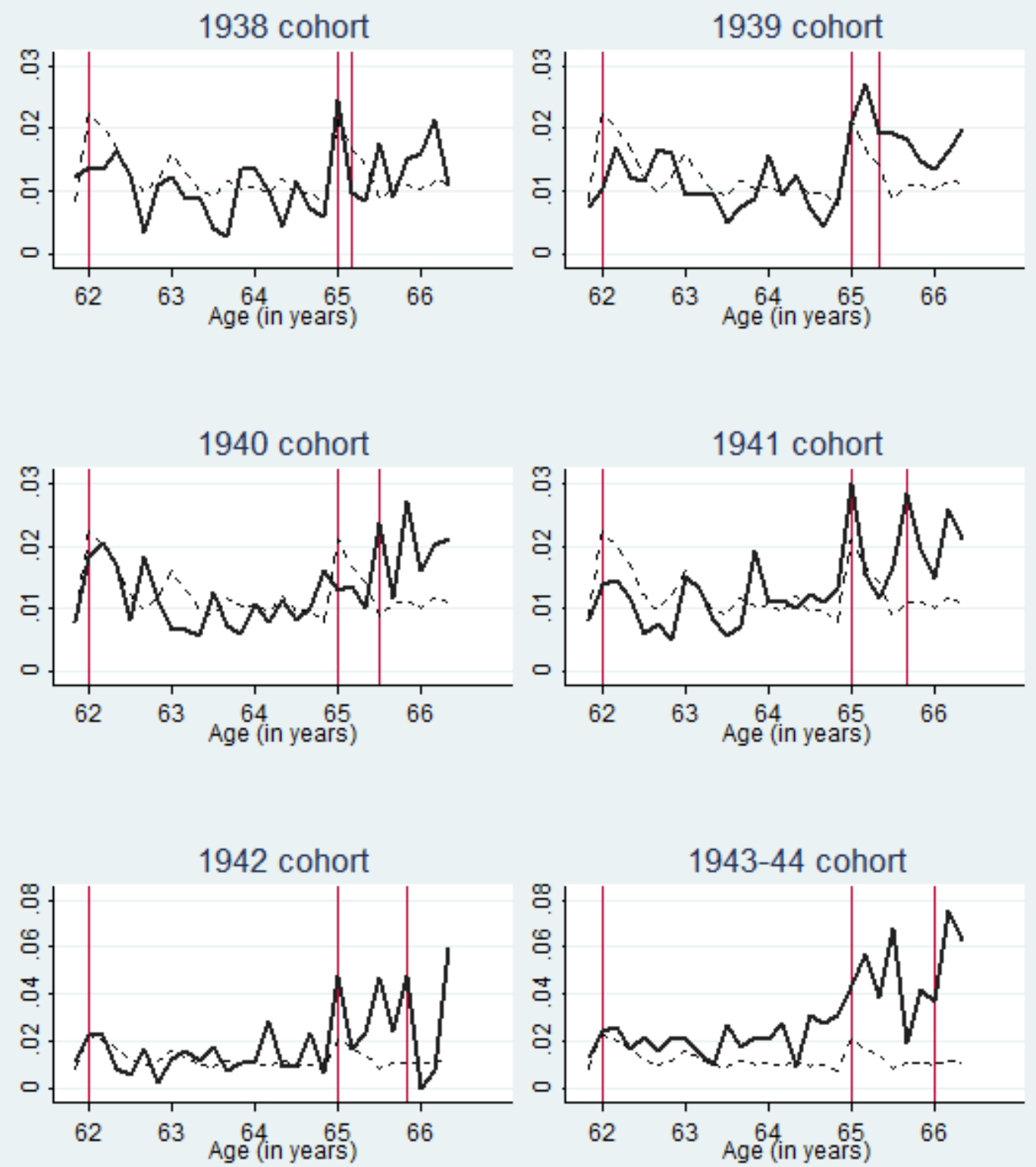

Notes: The graphs show the average monthly hazard of exit from employment rates for cohorts born in between 1931 to 1944. The hazard of exit from employment rate is defined as the probability of exit at a given age, conditional on being employed in the previous 3 months and not being employed in the next 3 months. Age is measured at a bimonthly frequency; e.g. age 62 denotes age 744 and 745 in months. In each graph, the dotted line depicts the claiming hazard for workers with Full Retirement Age (FRA) of 65. For each cohort, the vertical lines indicate age 62, age 65, and the FRA. 


\section{Figure 4: Hazard of Retirement}
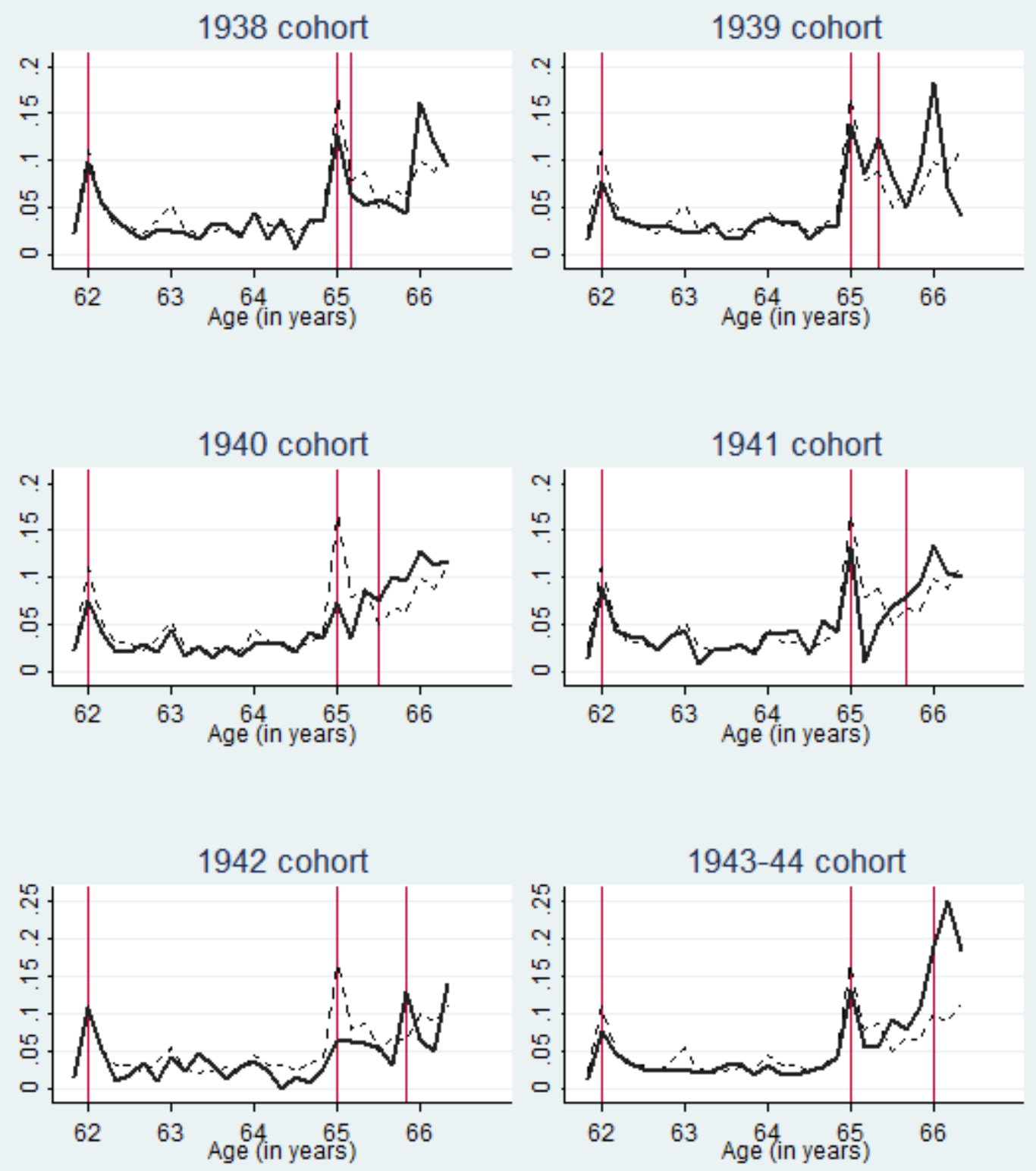

Notes: The graphs show the average monthly hazard of retirement rates for cohorts born in between 1931 to 1944. The hazard of retirement rate is defined as the probability of claiming to be retired at a given age on or after age 62 years, conditional on not having claimed to be retired between then and 62 with claiming being an absorbing state. Age is measured at a bimonthly frequency; e.g. age 62 denotes age 744 and 745 in months. In each graph, the dotted line depicts the claiming hazard for workers with Full Retirement Age (FRA) of 65. For each cohort, the vertical lines indicate age 62, age 65, and the FRA. 
Figure 5. The Difference between Expected and Calculated Social Security Benefits, by Claiming Age

Panel A: At age 62

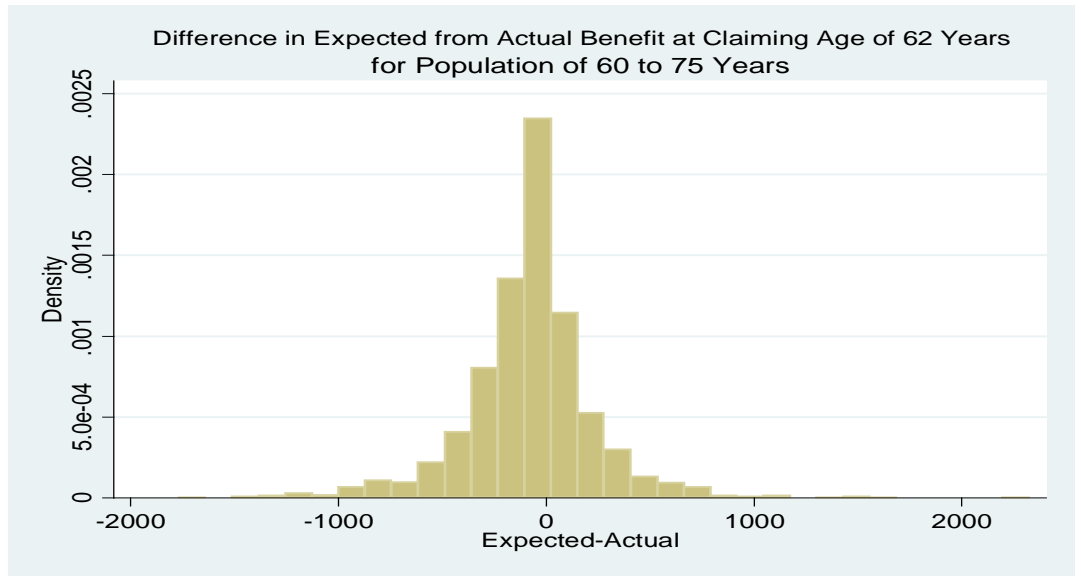

Panel B: At full retirement age

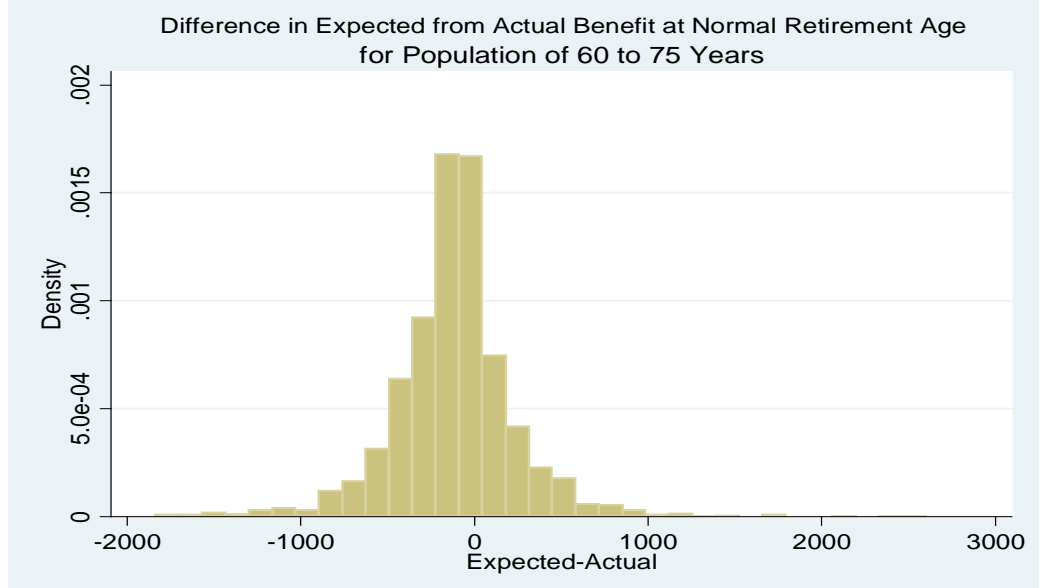

Panel C: At expected retirement age

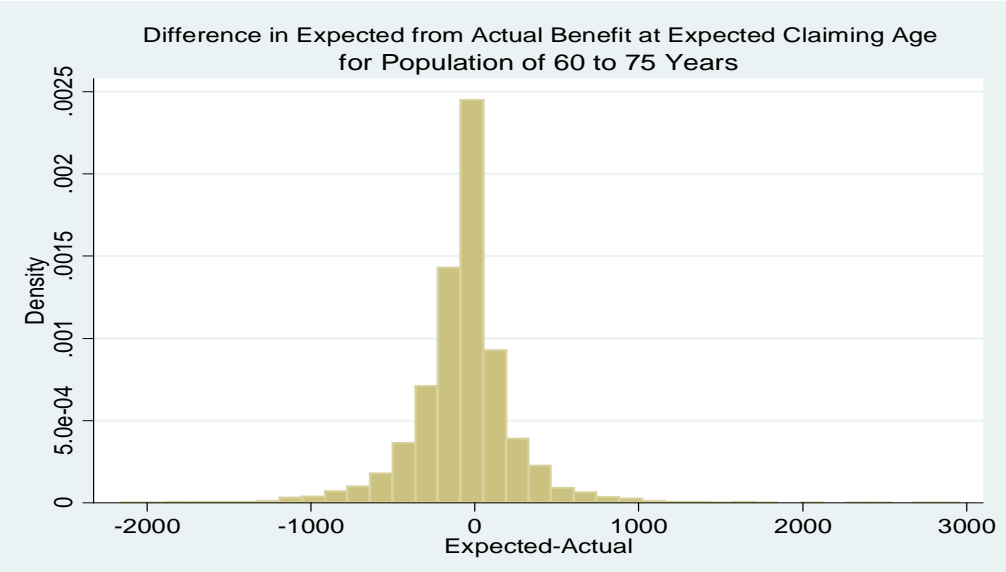


Table 1. Summary Statistics

\begin{tabular}{|c|c|c|c|c|}
\hline & All cohorts & 1938-42 Cohorts & 1943-44 Cohorts & \\
\hline Variable & Mean & Mean & Mean & Mean \\
\hline Earnings test removed cohort & 0.67 & 0.42 & 1.00 & 1.00 \\
\hline \multicolumn{5}{|l|}{ Race } \\
\hline African American & 0.14 & 0.14 & 0.14 & 0.13 \\
\hline Hispanic & 0.07 & 0.07 & 0.08 & 0.06 \\
\hline Female & 0.50 & 0.48 & 0.52 & 0.55 \\
\hline Married & 0.71 & 0.72 & 0.71 & $\begin{array}{l}0.72 \\
13.4\end{array}$ \\
\hline Education (in years) & 12.72 & 12.48 & 12.97 & 8 \\
\hline Fair or poor health & 0.18 & 0.18 & 0.17 & 0.15 \\
\hline Pension on current job & 0.12 & 0.13 & 0.10 & 0.11 \\
\hline Pension on current job - don't & & & & \\
\hline know & 0.78 & 0.75 & 0.80 & 0.83 \\
\hline DB pension on current job & 0.14 & 0.14 & 0.13 & 0.10 \\
\hline DB pension on current job - don't & & & & \\
\hline know & 0.01 & 0.01 & 0.02 & 0.04 \\
\hline Household wealth $(\$ 100,000)$ & 4.96 & 3.86 & 6.22 & $\begin{array}{l}7.34 \\
17.8\end{array}$ \\
\hline Wage (hourly) & 16.02 & 14.48 & 18.08 & 4 \\
\hline Wage - don't know & 0.11 & 0.09 & 0.13 & 0.10 \\
\hline High TICS score & 0.22 & 0.32 & 0.09 & 0.11 \\
\hline High memory score & 0.60 & 0.56 & 0.64 & 0.66 \\
\hline Salaried & 0.19 & 0.17 & 0.22 & 0.21 \\
\hline Salaried - unknown & 0.43 & 0.46 & 0.38 & 0.38 \\
\hline Self-employed & 0.17 & 0.15 & 0.19 & 0.18 \\
\hline Self-employed - unknown & 0.26 & 0.31 & 0.19 & 0.20 \\
\hline Health insurance & & & & \\
\hline Employer & 0.52 & 0.49 & 0.56 & 0.55 \\
\hline Government & 0.23 & 0.25 & 0.19 & 0.20 \\
\hline Other & 0.04 & 0.03 & 0.06 & 0.09 \\
\hline Spouse's employer & 0.17 & 0.16 & 0.18 & 0.18 \\
\hline $\begin{array}{l}\text { Spouse HI from spouse's } \\
\text { employer }\end{array}$ & 0.27 & 0.26 & 0.29 & 0.26 \\
\hline No retiree health insurance & 0.69 & 0.74 & 0.62 & 0.60 \\
\hline $\begin{array}{l}\text { Retiree health insurance - } \\
\text { unknown }\end{array}$ & 0.16 & 0.21 & 0.11 & 0.09 \\
\hline $\begin{array}{l}\text { Average indexed monthly } \\
\text { earnings at } 64\end{array}$ & & & & 2,80 \\
\hline (lifetime earnings measure) & 2,252 & 1,900 & 2,576 & 5 \\
\hline Observations & 3,717 & 2,109 & 1,363 & 245 \\
\hline
\end{tabular}


Table 2. Baseline Results of Social Security Program and Labor Market Outcomes

\begin{tabular}{|c|c|c|c|}
\hline & $(1)$ & $(2)$ & (3) \\
\hline \multicolumn{4}{|c|}{ Panel A: Claiming Social Security } \\
\hline FRA dummy & $\begin{array}{l}0.1498^{* * *} \\
(0.017)\end{array}$ & $\begin{array}{l}0.1488^{* * *} \\
(0.017)\end{array}$ & $\begin{array}{l}0.1488 * * * \\
(0.017)\end{array}$ \\
\hline Month when turns 65 & $\begin{array}{l}0.1509^{* * *} \\
(0.014)\end{array}$ & $\begin{array}{l}0.1480^{* *} \\
(0.014)\end{array}$ & $\begin{array}{l}0.1480^{* *} \\
(0.014)\end{array}$ \\
\hline Month when turns 64 & $\begin{array}{l}0.0123^{* * *} \\
(0.006)\end{array}$ & $\begin{array}{l}0.0162^{* * *} \\
(0.006)\end{array}$ & $\begin{array}{l}0.0162^{* * *} \\
(0.006)\end{array}$ \\
\hline Earnings test removal cohorts & & & $\begin{array}{l}0.0473^{* * *} \\
(0.010)\end{array}$ \\
\hline \multicolumn{4}{|c|}{ Panel B: Exit from the labor force hazard } \\
\hline FRA dummy & $\begin{array}{c}0.0052 \\
(0.007)\end{array}$ & $\begin{array}{r}0.003 \\
(0.007)\end{array}$ & $\begin{array}{r}0.003 \\
(0.007)\end{array}$ \\
\hline Month when turns 65 & $\begin{array}{r}0.0108 \\
(0.007)\end{array}$ & $\begin{array}{c}0.0130 * \\
(0.007)\end{array}$ & $\begin{array}{l}0.0130 * \\
(0.007)\end{array}$ \\
\hline Month when turns 64 & $\begin{array}{r}-0.0035 \\
(0.004)\end{array}$ & $\begin{array}{r}-0.0041 \\
(0.004)\end{array}$ & $\begin{array}{r}-0.0041 \\
(0.004)\end{array}$ \\
\hline Earnings test removal cohorts & & & $\begin{array}{l}0.0297^{* * *} \\
(0.010)\end{array}$ \\
\hline \multicolumn{4}{|l|}{ Panel C: Retirement hazard } \\
\hline FRA dummy & $\begin{array}{l}0.0256^{* * *} \\
(0.010)\end{array}$ & $\begin{array}{l}0.0238^{* *} \\
(0.010)\end{array}$ & $\begin{array}{l}0.0238^{* *} \\
(0.010)\end{array}$ \\
\hline Month when turns 65 & $\begin{array}{l}0.0657 * * * \\
(0.010)\end{array}$ & $\begin{array}{l}0.0662^{* * *} \\
(0.010)\end{array}$ & $\begin{array}{l}0.0662^{* * *} \\
(0.010)\end{array}$ \\
\hline Month when turns 64 & $\begin{array}{l}0.0152^{* * *} \\
(0.006)\end{array}$ & $\begin{array}{l}0.0152^{* * *} \\
(0.006)\end{array}$ & $\begin{array}{l}0.0152^{* * *} \\
(0.006)\end{array}$ \\
\hline Earnings test removal cohorts & & & $\begin{array}{l}0.0036 \\
(0.005)\end{array}$ \\
\hline Observations & 30,214 & 30,141 & 30,141 \\
\hline
\end{tabular}

Standard errors in parentheses

Notes: a) Model 1 has cohort and age fixed effects only; model 2 adds the individual controls; model 3 adds Earnings Test Removal indicator model 2.

b) Controls in models (2) \& (3): race, sex, marital status, education, health, health insurance coverage, retiree health insurance coverage, pension coverage, pension type, household wealth, average hourly earnings, and measures of cognitive capability, planning horizon, and risk aversion.

c) Sample: HRS waves 1996-2010, cohorts born in 1931-44.

d) Age range included in the regression is 64-66.

e) The models were estimated by OLS with standard errors clustered by individual.

${ }^{*} \mathrm{p}<0.10,{ }^{* *} \mathrm{p}<0.05, * * * \mathrm{p}<0.01$ 
Table 3. Descriptive Statistics of Social Security Knowledge

\begin{tabular}{|c|c|c|c|c|c|c|c|c|c|c|c|c|}
\hline \multirow[b]{2}{*}{ Variable } & \multicolumn{3}{|c|}{ All cohorts } & \multicolumn{3}{|c|}{ 1931-37 Cohorts } & \multicolumn{3}{|c|}{ 1938-42 Cohorts } & \multicolumn{3}{|c|}{ 1943-44 Cohorts } \\
\hline & Obs & Mean & Std. dev. & Obs & Mean & Std. dev. & Obs & Mean & Std. dev. & Obs & Mean & Std. dev. \\
\hline Expected age of retirement & 1,626 & 65.1 & 1.7 & 593 & 65.1 & 1.8 & 854 & 65.1 & 1.6 & 179 & 66.6 & 1.7 \\
\hline Expected SS benefit at expected retirement & & & & & & & & & & & & \\
\hline age & 1,540 & 1,022 & 490.5 & 764 & 866 & 387.2 & 642 & 1,160 & 516.2 & 134 & 1,251 & 595.6 \\
\hline Calculated benefits at expected retirement age & 1,231 & 1,164 & 476.4 & 408 & 1,019 & 380.1 & 685 & 1,214 & 496.6 & 138 & 1,346 & 518.8 \\
\hline Expected SS benefit at $62^{1}$ & 277 & 871 & 432.6 & 0 & -- & -- & 222 & 853 & 427.0 & 55 & 946 & 450.8 \\
\hline Calculated benefits at age 62 & 2,484 & 781 & 329.8 & 1,236 & 679 & 268.4 & 1,060 & 874 & 352.2 & 188 & 932 & 353.2 \\
\hline Expected SS benefit at FRA ${ }^{1}$ & 455 & 1,191 & 517.1 & 0 & -- & -- & 391 & 1,190 & 513.6 & 64 & 1,203 & 542.0 \\
\hline Calculated benefits at FRA & 2,611 & 1,036 & 435.0 & 1,341 & 889 & 335.8 & 1,082 & 1,169 & 468.1 & 188 & 1,317 & 479.3 \\
\hline
\end{tabular}

${ }^{1}$ Expected Social Security benefits at age 62 and the FRA were added to the HRS in 2002, and only asked of people who have not yet reached those ages. Thus we do not know the expectations of the earlier cohort. 
Table 4. Sensitivity to Social Security Knowledge

\begin{tabular}{|c|c|c|c|}
\hline & $(1)$ & $(2)$ & $(3)$ \\
\hline & Age 62 & FRA & Self-reported retirement age \\
\hline Panel A: Claiming Social Security & & & \\
\hline FRA dummy $*$ slight underestimation & 0.0162 & -0.1142 & -0.0556 \\
\hline & $(0.086)$ & $(0.096)$ & $(0.055)$ \\
\hline FRA* large overestimation & -0.1696 & -0.1238 & 0.0233 \\
\hline & $(0.119)$ & $(0.139)$ & $(0.101)$ \\
\hline FRA* large underestimation & -0.0162 & -0.0393 & -0.0508 \\
\hline & $(0.117)$ & $(0.117)$ & $(0.068)$ \\
\hline FRA * no response & 0.0378 & -0.0977 & $-0.1445 * * *$ \\
\hline & $(0.084)$ & $(0.101)$ & $(0.053)$ \\
\hline Age $65 *$ slight underestimation & 0.0518 & 0.0646 & 0.0259 \\
\hline & $(0.050)$ & $(0.050)$ & $(0.039)$ \\
\hline Age $65 *$ large overestimation & 0.1333 & 0.0049 & -0.0344 \\
\hline & $(0.094)$ & $(0.101)$ & $(0.071)$ \\
\hline Age $65 *$ large underestimation & 0.0947 & 0.0114 & -0.0337 \\
\hline & $(0.071)$ & $(0.064)$ & $(0.049)$ \\
\hline Age $65 *$ no response & 0.0571 & 0.0128 & 0.0503 \\
\hline & $(0.046)$ & $(0.055)$ & $(0.040)$ \\
\hline Age $64 *$ slight underestimation & -0.0189 & 0.0248 & 0.0157 \\
\hline & $(0.031)$ & $(0.028)$ & $(0.016)$ \\
\hline Age $64 *$ large overestimation & -0.0236 & 0.0089 & -0.0238 \\
\hline & $(0.023)$ & $(0.067)$ & $(0.035)$ \\
\hline Age $64 *$ large underestimation & 0.0001 & 0.0036 & -0.0055 \\
\hline & $(0.032)$ & $(0.035)$ & $(0.018)$ \\
\hline Age $64 *$ no response & 0.005 & 0.0217 & 0.0162 \\
\hline & $(0.028)$ & $(0.031)$ & $(0.015)$ \\
\hline Panel B: Exit from the labor force haza & & & \\
\hline FRA dummy * slight underestimation & 0.0083 & -0.0712 & -0.0026 \\
\hline & $(0.054)$ & $(0.048)$ & $(0.022)$ \\
\hline FRA * large overestimation & -0.0672 & -0.0864 & -0.0398 \\
\hline & $(0.080)$ & $(0.057)$ & $(0.025)$ \\
\hline FRA * large underestimation & -0.0438 & -0.067 & $-0.0393 *$ \\
\hline & $(0.049)$ & $(0.064)$ & $(0.022)$ \\
\hline FRA * no response & 0.0311 & -0.0126 & -0.0073 \\
\hline & $(0.054)$ & $(0.052)$ & $(0.021)$ \\
\hline Age $65 *$ slight underestimation & 0 & -0.0014 & -0.0155 \\
\hline & $(0.042)$ & $(0.041)$ & $(0.022)$ \\
\hline Age $65 *$ large overestimation & -0.0381 & -0.0995 & -0.0691 \\
\hline & $(0.034)$ & $(0.089)$ & $(0.044)$ \\
\hline Age $65 *$ large underestimation & -0.0262 & 0.0097 & 0.0019 \\
\hline & $(0.036)$ & $(0.045)$ & $(0.026)$ \\
\hline Age $65 *$ no response & -0.0138 & -0.0494 & -0.0215 \\
\hline & $(0.040)$ & $(0.046)$ & $(0.023)$ \\
\hline
\end{tabular}


Table 4. Sensitivity to Social Security Knowledge (cont’d)

\begin{tabular}{|c|c|c|c|}
\hline \multirow{4}{*}{ Age $64 *$ slight underestimation } & (1) & $(2)$ & (3) \\
\hline & Age 62 & FRA & Self-reported retirement age \\
\hline & -0.0048 & -0.0181 & -0.0021 \\
\hline & $(0.031)$ & $(0.031)$ & $(0.014)$ \\
\hline \multirow[t]{2}{*}{ Age $64 *$ large overestimation } & -0.0286 & -0.1348 & -0.0362 \\
\hline & $(0.032)$ & $(0.091)$ & $(0.049)$ \\
\hline \multirow[t]{2}{*}{ Age $64 *$ large underestimation } & -0.0085 & -0.013 & 0.0018 \\
\hline & $(0.028)$ & $(0.030)$ & $(0.016)$ \\
\hline \multirow[t]{2}{*}{ Age $64 *$ no response } & 0.0075 & 0.0049 & -0.0043 \\
\hline & $(0.028)$ & $(0.033)$ & $(0.015)$ \\
\hline \multicolumn{4}{|l|}{ Panel C: Retirement hazard } \\
\hline \multirow[t]{2}{*}{ FRA dummy * slight underestimation } & -0.075 & -0.0431 & 0.014 \\
\hline & $(0.067)$ & $(0.060)$ & $(0.030)$ \\
\hline \multirow[t]{2}{*}{ FRA * large overestimation } & $-0.0978^{*}$ & 0.0529 & 0.0682 \\
\hline & $(0.059)$ & $(0.132)$ & $(0.073)$ \\
\hline \multirow[t]{2}{*}{ FRA * large underestimation } & $-0.1434^{* *}$ & -0.0197 & 0.0535 \\
\hline & $(0.064)$ & $(0.080)$ & $(0.047)$ \\
\hline \multirow[t]{2}{*}{ FRA * no response } & -0.0752 & -0.03 & -0.0354 \\
\hline & $(0.065)$ & $(0.064)$ & $(0.030)$ \\
\hline \multirow[t]{2}{*}{ Age $65 *$ slight underestimation } & -0.0099 & 0.0772 & 0.0013 \\
\hline & $(0.042)$ & $(0.048)$ & $(0.029)$ \\
\hline \multirow[t]{2}{*}{ Age $65 *$ large overestimation } & 0.2014 & 0.0022 & 0.0402 \\
\hline & $(0.159)$ & $(0.044)$ & $(0.055)$ \\
\hline \multirow[t]{2}{*}{ Age $65 *$ large underestimation } & 0.0736 & 0.0849 & $-0.0803^{*}$ \\
\hline & $(0.074)$ & (0.069) & $(0.045)$ \\
\hline \multirow[t]{2}{*}{ Age $65 *$ no response } & 0.0172 & 0.0287 & 0.0426 \\
\hline & $(0.040)$ & $(0.054)$ & $(0.031)$ \\
\hline \multirow[t]{2}{*}{ Age $64 *$ slight underestimation } & 0.0234 & $0.0737^{*}$ & 0.0166 \\
\hline & $(0.023)$ & $(0.038)$ & $(0.018)$ \\
\hline \multirow[t]{2}{*}{ Age $64 *$ large overestimation } & 0.0814 & 0.0502 & 0.0161 \\
\hline & $(0.086)$ & $(0.089)$ & $(0.027)$ \\
\hline \multirow[t]{2}{*}{ Age $64 *$ large underestimation } & 0.0118 & -0.0075 & -0.0035 \\
\hline & $(0.008)$ & $(0.042)$ & $(0.031)$ \\
\hline \multirow[t]{2}{*}{ Age $64 *$ no response } & 0.03 & 0.0573 & 0.0068 \\
\hline & $(0.019)$ & $(0.043)$ & $(0.017)$ \\
\hline Observations & & & \\
\hline
\end{tabular}

Standard errors in parentheses

Notes: a) All models include all controls as model 3 in Table 2.

b) Sample: HRS waves 1996-2010, cohorts born in 1931-44.

c) Age range included in the regression is 64-66.

d) The models were estimated by OLS with clustered standard errors at the individual.

${ }^{*} \mathrm{p}<0.10,{ }^{* *} \mathrm{p}<0.05,{ }^{* * *} \mathrm{p}<0.01$ 
Table 5. Sensitivity to Retiree Health Insurance

(1)

\begin{tabular}{lc}
\hline Panel A: Claiming Social Security & \\
\hline FRA dummy * no retiree health insurance & -0.0453 \\
& $(0.047)$ \\
Age $65 *$ no retiree health insurance & -0.0189 \\
& $(0.033)$ \\
& -0.0085 \\
Age $64 *$ no retiree health insurance & $(0.013)$ \\
\hline & 0.0131 \\
\hline Panel B: Exit from the labor force hazard & $(0.020)$ \\
\hline FRA dummy * no retiree health insurance & 0.0163 \\
& $(0.019)$ \\
Age $65 *$ no retiree health insurance & 0.005 \\
& $(0.010)$ \\
\hline Age $64 *$ no retiree health insurance & $-0.0575 * *$ \\
& $(0.028)$ \\
\hline Panel C: Retirement hazard & $0.0748^{* * *}$ \\
\hline FRA dummy * no retiree health insurance & $(0.023)$ \\
Age $65 *$ no retiree health insurance & -0.0058 \\
& $(0.013)$ \\
\hline
\end{tabular}

Observations

Standard errors in parentheses

Notes: a) All models include all controls as model 3 in Table 2.

b) Sample: HRS waves 1996-2010, cohorts born in 1931-44.

c) Age range included in the regression is 64-66.

d) The models were estimated by OLS with clustered standard errors at the individual.

${ }^{*} \mathrm{p}<0.10,{ }^{* *} \mathrm{p}<0.05,{ }^{* * *} \mathrm{p}<0.01$ 
Appendix Table 1. Full Baseline Results of Social Security Program and Labor Market Outcomes

\begin{tabular}{|c|c|c|c|c|c|c|}
\hline \multirow[b]{4}{*}{ FRA indicator } & \multirow{2}{*}{\multicolumn{2}{|c|}{$\begin{array}{c}(1) \\
\text { Claim Social Security }\end{array}$}} & \multirow{2}{*}{\multicolumn{2}{|c|}{$\begin{array}{c}\text { (2) } \\
\text { Exit the labor force }\end{array}$}} & \multirow{2}{*}{\multicolumn{2}{|c|}{$\begin{array}{c}(3) \\
\text { Retire }\end{array}$}} \\
\hline & & & & & & \\
\hline & Coef. & Std. error & Coef. & Std. error & Coef. & Std. error \\
\hline & 0.1488 & $(0.0165)$ & 0.0030 & $(0.0065)$ & 0.0238 & $(0.0095)$ \\
\hline \multicolumn{7}{|l|}{ Race } \\
\hline African American & -0.0122 & $(0.0045)$ & -0.0088 & $(0.0022)$ & -0.0028 & $(0.0029)$ \\
\hline Hispanic & -0.0142 & $(0.0053)$ & 0.0027 & $(0.0034)$ & 0.0046 & $(0.0050)$ \\
\hline Female & 0.0027 & $(0.0030)$ & -0.0002 & $(0.0018)$ & -0.0007 & $(0.0021)$ \\
\hline Married & 0.0078 & $(0.0034)$ & -0.0043 & $(0.0020)$ & 0.0007 & $(0.0024)$ \\
\hline Education (in years) & -0.0015 & $(0.0006)$ & -0.0002 & $(0.0003)$ & -0.0004 & $(0.0004)$ \\
\hline Fair or poor health & -0.0060 & $(0.0042)$ & 0.0099 & $(0.0024)$ & -0.0007 & $(0.0029)$ \\
\hline Pension on current job & 0.0199 & $(0.0087)$ & 0.0046 & $(0.0043)$ & 0.0131 & $(0.0062)$ \\
\hline Pension on current job -don't know & -0.0046 & $(0.0072)$ & -0.0137 & $(0.0033)$ & -0.0080 & $(0.0045)$ \\
\hline DB pension on current job & -0.0021 & $(0.0033)$ & 0.0048 & $(0.0020)$ & 0.0040 & $(0.0024)$ \\
\hline DB pension on current job - don't know & -0.0081 & $(0.0081)$ & 0.0014 & $(0.0067)$ & -0.0015 & $(0.0066)$ \\
\hline Household wealth & -0.0001 & $(0.0000)$ & 0.0000 & $(0.0000)$ & 0.0000 & $(0.0000)$ \\
\hline Wage & -0.0035 & $(0.0015)$ & -0.0015 & $(0.0015)$ & 0.0026 & $(0.0028)$ \\
\hline Wage - don't know & 0.0018 & $(0.0042)$ & -0.0010 & $(0.0022)$ & 0.0012 & $(0.0031)$ \\
\hline High numeracy & 0.0035 & $(0.0041)$ & 0.0004 & $(0.0026)$ & 0.0050 & $(0.0030)$ \\
\hline Numeracy - unknown & -0.0203 & $(0.0080)$ & 0.0001 & $(0.0035)$ & 0.0093 & $(0.0044)$ \\
\hline High TICS score & 0.0021 & $(0.0032)$ & 0.0024 & $(0.0019)$ & 0.0033 & $(0.0022)$ \\
\hline High memory score & -0.0011 & $(0.0030)$ & -0.0019 & $(0.0018)$ & 0.0011 & $(0.0021)$ \\
\hline Long financial planning horizon & -0.0043 & $(0.0040)$ & 0.0020 & $(0.0024)$ & 0.0024 & $(0.0028)$ \\
\hline Financial planning horizon - missing & -0.0123 & $(0.0066)$ & -0.0006 & $(0.0039)$ & -0.0022 & $(0.0043)$ \\
\hline Risk averse & 0.0015 & $(0.0043)$ & 0.0003 & $(0.0028)$ & -0.0003 & $(0.0033)$ \\
\hline Rick aversion - missing & 0.0068 & $(0.0054)$ & 0.0099 & $(0.0033)$ & 0.0055 & $(0.0036)$ \\
\hline Salaried & -0.0062 & $(0.0032)$ & 0.0000 & $(0.0018)$ & -0.0083 & $(0.0022)$ \\
\hline Salaried - unknown & -0.0594 & $(0.0321)$ & 0.0055 & $(0.0167)$ & 0.0516 & $(0.0240)$ \\
\hline Self-employed & 0.0507 & $(0.0323)$ & -0.0022 & $(0.0167)$ & -0.0514 & $(0.0243)$ \\
\hline
\end{tabular}


Appendix Table 1. Full Baseline Results of Social Security Program and Labor Market Outcomes (cont'd)

\begin{tabular}{|c|c|c|c|c|c|c|}
\hline \multirow[b]{4}{*}{ Self-employed - unknown } & \multirow{2}{*}{\multicolumn{2}{|c|}{$\frac{(1)}{\text { Claim Social Security }}$}} & \multirow{2}{*}{\multicolumn{2}{|c|}{$\begin{array}{c}\text { (2) } \\
\text { Exit the labor force }\end{array}$}} & \multirow{2}{*}{\multicolumn{2}{|c|}{$\begin{array}{c}(3) \\
\text { Retire }\end{array}$}} \\
\hline & & & & & & \\
\hline & Coef. & Std. error & Coef. & Std. error & Coef. & Std. error \\
\hline & 0.0679 & $(0.0324)$ & 0.0352 & $(0.0170)$ & -0.0034 & $(0.0238)$ \\
\hline \multicolumn{7}{|l|}{ Health insurance } \\
\hline Employer & 0.0042 & $(0.0108)$ & 0.0112 & $(0.0066)$ & -0.0041 & $(0.0089)$ \\
\hline Government & -0.0001 & $(0.0073)$ & -0.0069 & $(0.0047)$ & -0.0089 & $(0.0053)$ \\
\hline Other & -0.0056 & $(0.0132)$ & -0.0179 & $(0.0085)$ & -0.0246 & $(0.0111)$ \\
\hline Spouse's employer & 0.0024 & $(0.0126)$ & 0.0161 & $(0.0090)$ & 0.0024 & $(0.0106)$ \\
\hline Spouse HI from spouse's employer & -0.0110 & $(0.0064)$ & -0.0018 & $(0.0043)$ & 0.0012 & $(0.0051)$ \\
\hline Retiree health insurance & -0.0101 & $(0.0118)$ & 0.0065 & $(0.0073)$ & -0.0026 & $(0.0096)$ \\
\hline Retiree health insurance - unknown & -0.0006 & $(0.0041)$ & 0.0028 & $(0.0027)$ & -0.0013 & $(0.0032)$ \\
\hline ETR_cohort & 0.0473 & $(0.0104)$ & 0.0297 & $(0.0095)$ & -0.0036 & $(0.0049)$ \\
\hline \multicolumn{7}{|l|}{ Age (in months) } \\
\hline 768 (64 years) & 0.0162 & $(0.0057)$ & -0.0041 & $(0.0043)$ & 0.0152 & $(0.0057)$ \\
\hline 769 & 0.0242 & $(0.0060)$ & 0.0086 & $(0.0049)$ & 0.0040 & $(0.0052)$ \\
\hline 770 & -0.0016 & $(0.0048)$ & 0.0000 & $(0.0045)$ & 0.0040 & $(0.0052)$ \\
\hline 771 & -0.0044 & $(0.0047)$ & 0.0028 & $(0.0047)$ & -0.0014 & $(0.0049)$ \\
\hline 772 & -0.0065 & $(0.0046)$ & 0.0005 & $(0.0045)$ & 0.0008 & $(0.0051)$ \\
\hline 773 & -0.0020 & $(0.0049)$ & 0.0024 & $(0.0047)$ & 0.0011 & $(0.0051)$ \\
\hline \multicolumn{7}{|l|}{774 (omitted group) } \\
\hline 775 & -0.0064 & $(0.0047)$ & 0.0013 & $(0.0046)$ & -0.0095 & $(0.0043)$ \\
\hline 776 & -0.0033 & $(0.0049)$ & 0.0020 & $(0.0047)$ & -0.0023 & $(0.0049)$ \\
\hline 777 & 0.0033 & $(0.0054)$ & -0.0002 & $(0.0046)$ & 0.0052 & $(0.0055)$ \\
\hline 778 & 0.0152 & $(0.0061)$ & 0.0012 & $(0.0047)$ & 0.0026 & $(0.0054)$ \\
\hline 779 & 0.0236 & $(0.0066)$ & -0.0035 & $(0.0044)$ & 0.0082 & $(0.0057)$ \\
\hline 780 (65 years) & 0.1480 & $(0.0138)$ & 0.0130 & $(0.0071)$ & 0.0662 & $(0.0101)$ \\
\hline 781 & 0.2103 & $(0.0132)$ & 0.0410 & $(0.0065)$ & 0.0329 & $(0.0074)$ \\
\hline 782 & 0.0718 & $(0.0111)$ & 0.0119 & $(0.0054)$ & 0.0046 & $(0.0060)$ \\
\hline
\end{tabular}


Appendix Table 1. Full Baseline Results of Social Security Program and Labor Market Outcomes (cont'd)

\begin{tabular}{|c|c|c|c|c|c|c|}
\hline & \multicolumn{2}{|c|}{$(1)$} & \multicolumn{2}{|c|}{$(2)$} & \multicolumn{2}{|c|}{$(3)$} \\
\hline & \multicolumn{2}{|c|}{ Claim Social Security } & \multicolumn{2}{|c|}{ Exit the labor force } & \multicolumn{2}{|c|}{ Retire } \\
\hline & Coef. & Std. error & Coef. & Std. error & Coef. & Std. error \\
\hline 783 & 0.0940 & $(0.0120)$ & 0.0177 & $(0.0056)$ & 0.0227 & $(0.0070)$ \\
\hline 784 & 0.0457 & $(0.0105)$ & 0.0129 & $(0.0055)$ & 0.0138 & $(0.0067)$ \\
\hline 785 & 0.0706 & $(0.0118)$ & 0.0073 & $(0.0052)$ & 0.0234 & $(0.0072)$ \\
\hline 786 & 0.0643 & $(0.0125)$ & 0.0154 & $(0.0057)$ & 0.0028 & $(0.0060)$ \\
\hline 787 & 0.0635 & $(0.0125)$ & 0.0065 & $(0.0052)$ & 0.0179 & $(0.0071)$ \\
\hline 788 & 0.0378 & $(0.0123)$ & 0.0116 & $(0.0056)$ & 0.0014 & $(0.0061)$ \\
\hline 789 & 0.0627 & $(0.0134)$ & 0.0073 & $(0.0053)$ & 0.0149 & $(0.0070)$ \\
\hline 790 & 0.0336 & $(0.0123)$ & 0.0128 & $(0.0057)$ & 0.0184 & $(0.0073)$ \\
\hline 791 & 0.0409 & $(0.0127)$ & 0.0149 & $(0.0058)$ & 0.0051 & $(0.0062)$ \\
\hline 792 (66 years) & 0.2021 & $(0.0223)$ & -0.0001 & $(0.0049)$ & 0.0249 & $(0.0080)$ \\
\hline \multicolumn{7}{|l|}{ Birth cohort } \\
\hline \multicolumn{7}{|l|}{1931 (omitted) } \\
\hline 1932 & 0.0246 & $(0.0101)$ & -0.0051 & $(0.0057)$ & -0.0028 & $(0.0057)$ \\
\hline 1933 & 0.0261 & $(0.0104)$ & -0.0165 & $(0.0056)$ & \multicolumn{2}{|c|}{ (omitted) } \\
\hline 1934 & 0.0321 & $(0.0102)$ & -0.0111 & $(0.0055)$ & -0.0032 & $(0.0046)$ \\
\hline 1935 & \multicolumn{2}{|c|}{ (omitted) } & -0.0459 & $(0.0079)$ & \multicolumn{2}{|c|}{ (omitted) } \\
\hline 1936 & 0.0023 & $(0.0071)$ & -0.0424 & $(0.0074)$ & 0.0038 & $(0.0045)$ \\
\hline 1937 & -0.0107 & $(0.0086)$ & -0.0370 & $(0.0073)$ & 0.0058 & $(0.0052)$ \\
\hline 1938 & -0.0236 & $(0.0105)$ & -0.0341 & $(0.0071)$ & 0.0127 & $(0.0063)$ \\
\hline 1939 & -0.0250 & $(0.0111)$ & -0.0285 & $(0.0072)$ & 0.0148 & $(0.0065)$ \\
\hline 1940 & -0.0434 & $(0.0112)$ & -0.0340 & $(0.0075)$ & 0.0132 & $(0.0068)$ \\
\hline 1941 & -0.0422 & $(0.0110)$ & -0.0267 & $(0.0076)$ & 0.0122 & $(0.0067)$ \\
\hline 1942 & -0.0558 & $(0.0107)$ & -0.0101 & $(0.0081)$ & 0.0194 & $(0.0072)$ \\
\hline 1943 & -0.0546 & $(0.0111)$ & \multicolumn{2}{|c|}{ (omitted) } & 0.0247 & $(0.0079)$ \\
\hline 1944 & -0.0379 & $(0.0119)$ & 0.0148 & $(0.0128)$ & 0.0333 & $(0.0088)$ \\
\hline Constant & 0.0316 & $(0.0197)$ & 0.0165 & $(0.0116)$ & 0.0154 & $(0.0133)$ \\
\hline
\end{tabular}




\section{RECENT WORKING PAPERS FROM THE CENTER FOR RETIREMENT RESEARCH AT BOSTON COLLEGE}

Rethinking Optimal Wealth Accumulation and Decumulation Strategies in the Wake of the Financial Crisis

Richard W. Kopcke, Anthony Webb, and Josh Hurwitz, January 2013

Employee Mobility and Employer-Provided Retirement Plans

Gopi Shah Goda, Damon Jones, and Colleen Flaherty Manchester, November 2012

Changing Sources of Income among the Aged Population

Barry P. Bosworth and Kathleen Burke, November 2012

Holding Out or Opting Out? Deciding Between Retirement and Disability Applications in Recessions

Matthew S. Rutledge, November 2012

Automatic Enrollment, Employee Compensation, and Retirement Security

Barbara A. Butrica and Nadia S. Karamcheva, November 2012

401(k) Participant Behavior in a Volatile Economy

Barbara A. Butrica and Karen E. Smith, November 2012

Immigrant Networks and the Take-Up of Disability Programs: Evidence from U.S. Census Data

Delia Furtado and Nikolaos Theodoropoulos, October 2012

Growth in Health Consumption and Its Implications for Financing OASDI: An International Perspective

Barry P. Bosworth and Gary Burtless, September 2012

Using Participant Data to Improve 401(k) Asset Allocation

Zhenyu Li and Anthony Webb, September 2012

Job Demand and Early Retirement

Sepideh Modrek and Mark R. Cullen, August 2012

Changes in Labor Force Participation of Older Americans and Their Pension Structures: A Policy Perspective

Frank W. Heiland and Zhe Li, July 2012

All working papers are available on the Center for Retirement Research website (http://crr.bc.edu) and can be requested by e-mail (crr@bc.edu) or phone (617-552-1762). 